\title{
Author Correction: HYSOGs250m, global gridded hydrologic soil groups for curve-number-based runoff modeling
}

\section{Wade Ross ${ }^{1}$, Lara Prihodko ${ }^{2}$, Julius Anchang ${ }^{1}$, Sanath Kumar ${ }^{1}$, Wenjie Ji ${ }^{1}$ \& Niall P. Hanan ${ }^{1}$ \\ Correction to: Scientific Data https://doi.org/10.1038/sdata.2018.91; published online 15 May 2018}

The original version of this Data Descriptor incorrectly referenced the "United Nations (UN) Food and Agriculture Organization (FAO) soilGrids250m system". This has been corrected to "SoilGrids predictions" throughout the text in both the HTML and PDF versions.

In addition, the legend of Figure 4 incorrectly cited reference 15 in the paper. This has been corrected in the HTML and PDF versions to:

20. Shangguan, W., Hengl, T., Jesus, J.M. de, Yuan, H., \& Dai, Y. Mapping the global depth to bedrock for land surface modeling. Journal of Advances in Modeling Earth Systems. 9, 65-88 (2017).

(c) (i) Open Access This article is licensed under a Creative Commons Attribution 4.0 International License, which permits use, sharing, adaptation, distribution and reproduction in any medium or format, as long as you give appropriate credit to the original author(s) and the source, provide a link to the Creative Commons license, and indicate if changes were made. The images or other third party material in this article are included in the article's Creative Commons license, unless indicated otherwise in a credit line to the material. If material is not included in the article's Creative Commons license and your intended use is not permitted by statutory regulation or exceeds the permitted use, you will need to obtain permission directly from the copyright holder. To view a copy of this license, visit http://creativecommons.org/licenses/by/4.0/.

(c) The Author(s) 2019

${ }^{1}$ New Mexico State University, Department of Plant and Environmental Sciences, Las Cruces, New Mexico, 88003, USA. ${ }^{2}$ New Mexico State University, Department of Animal and Range Sciences, Las Cruces, New Mexico, 88003, USA. Correspondence and requests for materials should be addressed to C.W.R. (email: cwross@nmsu.edu) 